\section{FUNDAMENTAL IDEAS}

AND ACHIEVEMENTS OF HYDROGEN

ENERGY IN THE SERVICE OF THE MOON'S NTERIOR DEVELOPMENT

Vyacheslav A. BOBIN,

Doctor of Technical Sciences, Head of the

Department of the Institute for Problems

of Integrated Development of Subsoil

Resources of the Russian Academy of

Sciences, Moscow,

Anna V. BOBINA,
Candidate of Technical Sciences, Head of

the Department for Scientific Conferences and All-Russian Projects of the Free Economic Society of Russia,
annabobini@mail.ru
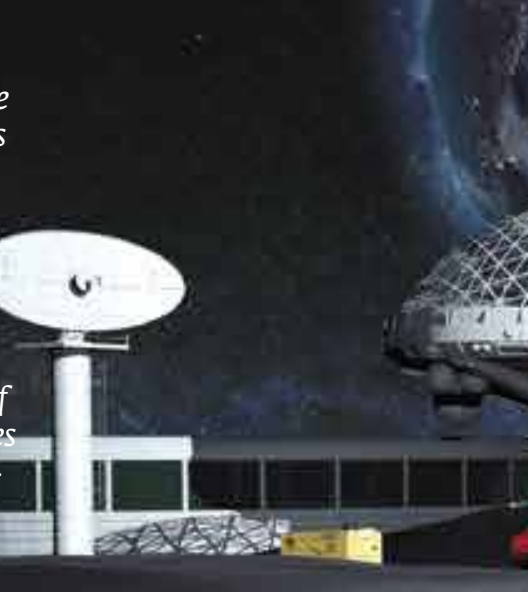

ФУНДАМЕНТАЛЬНЫЕ ИДЕИ И ДОСТИЖЕНИЯ ВОДОРОДНОИ ЭНЕРГЕТИКИ - НАСЛУЖБУ ОСВОЕНИЯНЕДР ЛУНЫ

Вячеслав Александрович БоБин доктор технических наук, заведуюший отделом Института проблем комплексного освоения неор РАН, Москва, Россия, bobin va@mail.ru

Анна Вяччеславовна БоБинА, андидат технцческих наук, руководитель и всероссийским проектам Вольного כкономического общестея России

Moсква, Россия,
annabobini@mail.ru
ABSTRACT I The paper analyzes fundamental ideas and achievements of hydrogen energy, as well as the prospects for their use for the development of the Moon's interior. Special attention is paid to solving the problem of water extraction and further hydrogen and oxygen production by thermal decomposition or electrolysis. The paper also focuses on the use of hydrogen and oxygen as fuel for power plants, internal combustion engines, fuel cells and rocket engines. An assumption is made about the possible places of free hydrogen release on the surface of the Moon.

Keywords: hydrogen energy, free hydrogen, sition of water, electrolysis, regolith, rare earth metals

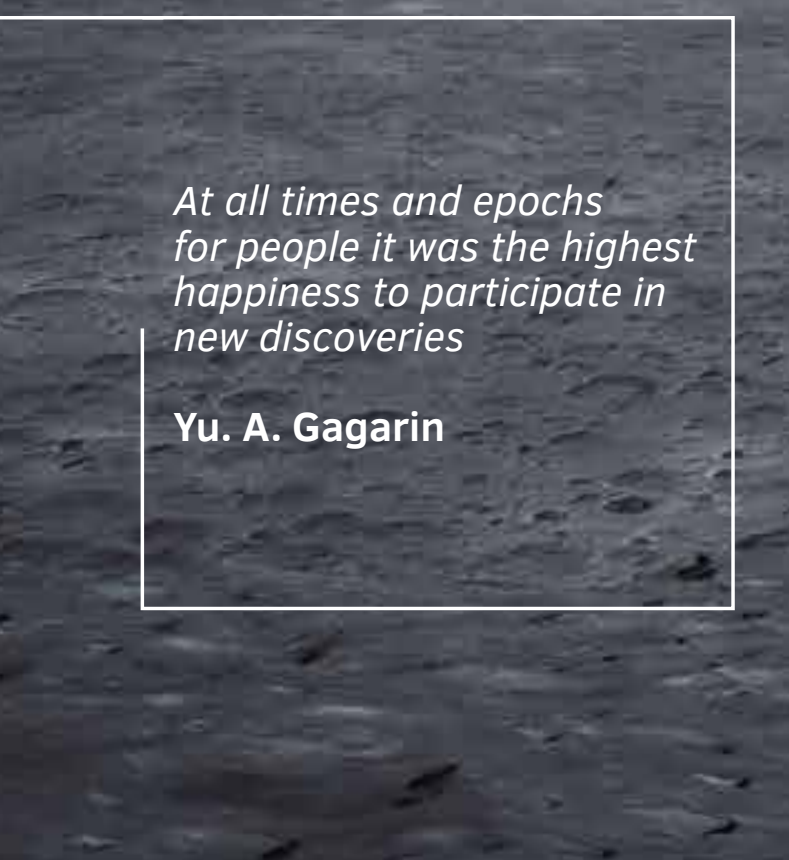

АННотАция I В работе проведен анализ фундаментальных идей и достижений водородной энергетики, а также перспектив их использования для освоения недр Луны. Особое внимание уделено проблеме добычи воды и получения из нее методом термического распада или электролиза водорода и кислорода, а также использованию их в качестве топлива для электростанций, двигателей внутреннего сгорания, топливных элементов и ракетных двигателей. Выдвинуто предположение о возможных местах выхода свободного водорода на поверхность Луны. Ключевые слова: водородная энергетика, свободный водород, водородная дегазация, кислород, термический распад воды, электролиз, реголит, редкоземельные 
нешние условия для работы как человека, так и созданных им механизмов и машин при извлечении полезных ископаемых на Луне характеризуются колебаниями температуры в несколько сотен градусов,
жестким рентгеновским и ультрафиолетовым излучением и абсолютным вакуумом, в кото ром мгновенно испаряется Полеты по программе «Аполлон» доказали, что астронавт в скафандре, защищенном 14 слоями специальных материалов, в состав и синтетические полиэфирные волокнания собен, имея ранцевую систему жизнеобеспече собен, имея ранцевую систему жизнеобеспечеПуны в условиях $-200^{\circ} \mathrm{C}$ и повышенной радиации. Скафандр позволяет астронавтам не толь-
ко перемещаться по лунной поверхности, но и осуществлять необходимые технологические операции, такие как строительство лунных поселений, разведка полезных ископаемых, установка средств связи и навигации, монтаж различных технологических устано вок по извлечению из лунных горных пород в первую очередь воды, кислорода, водорода доругих полезных ископаемых. И наиболе бот является реголит, покрыв орший дунну поверхность стоем различной толщины.

В последнее время интерес к реголиту провляется не только как к горной породе, сок источнику воды. Понятно, что вода является ключевым веществом, без которого невозможна жизнь не только на Луне, но и на Земле. Банально, но вода - это источник жизни, а кроме того, при ее термическом разложении или электролизе можно получать кислород для дьхания людей и растений, а в будущем - и для животных на Луне. И не только кислород, но и водород - основу водородной энергетики ва. Он будет необходим для космопланов, обес-

Опираясь на идентичность строения Земли и ее естественного спутника, можно предположкить, что и на Луне следует искать места естественной водородной дегазации и именно там осуществлять добычу водорода без особо крупных материальных затрат. печивающих полеты на окололунную и земпкже полеты на Марс и другие планеты Солнечной системы.

Согласно новым представлениям о внутреннем строении Луны, которые развивают ученые Рени Вебер (Renee Weber) из NASA и Paфаэль Гарсиа (Raphael Garcia, Франция), она ммеет свое раскаленное ядро, как и в случае емли, состоящее главным образом из железа. В то же время, согласно фундаментальным идеям профессора В. Н. Ларина о геохимических процессах, происходящих в глубинах земли, водород при образовании планет Солнечной системы активно участвовал во всех низт в том числе Луны и земли В твердом ядре он образовал гидриды, а в жидком внешнем ддре присутствовал в виде раствора в металте. При равновесных условиях гидриды устойчивы и не распадаются, однако при нарушении этих условий теряют водород, который диффундирует или фильтруется в верхние слои и выходит на поверхность по различным разломам в коре, что на Земле, например, проявляется в виде водородной дегазации [1]

Поэтому можно предположить, опираясь на идентичность строения Јемли и ее есте ственного спутника, возраст формирования которых совпадает, что и на Луне следует ис кать места естественной водородной дегазарода без особо ирупнх материальни затрат.

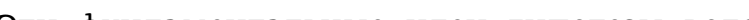
эти фундаментальные идеи гипотезы водозой для развития так называемой водородной энергетики, которая вследствие обострившихся экологических проблем настойчиво стремится потеснить углеродную энергетику, основанную на использовании природного метана, угл и нефти [2]. Многие наработки в этом направлении, без всякого сомнения, имеют реальную перспективу для прямого использования на Луне. К ним относятся, например, роторные двигатели внутреннего сгорания на водороде для лунных транспортных средств, водородтростанции на водороде типа Toshiba Н2One, которая обеспечивает мошность до 55 кВт при потреблении до 2,5 кубометра воды. Подобные электростанции могут работать в режиме замкнутого цикла, например совместно с установкой для самопроизвольного распада воды на водород и кислород при температуре более $1700{ }^{\circ} \mathrm{C}$. Такого значения температуры можно достигнуть на Луне при фокусировке солнечного света в одной точке с помощью линзы либо
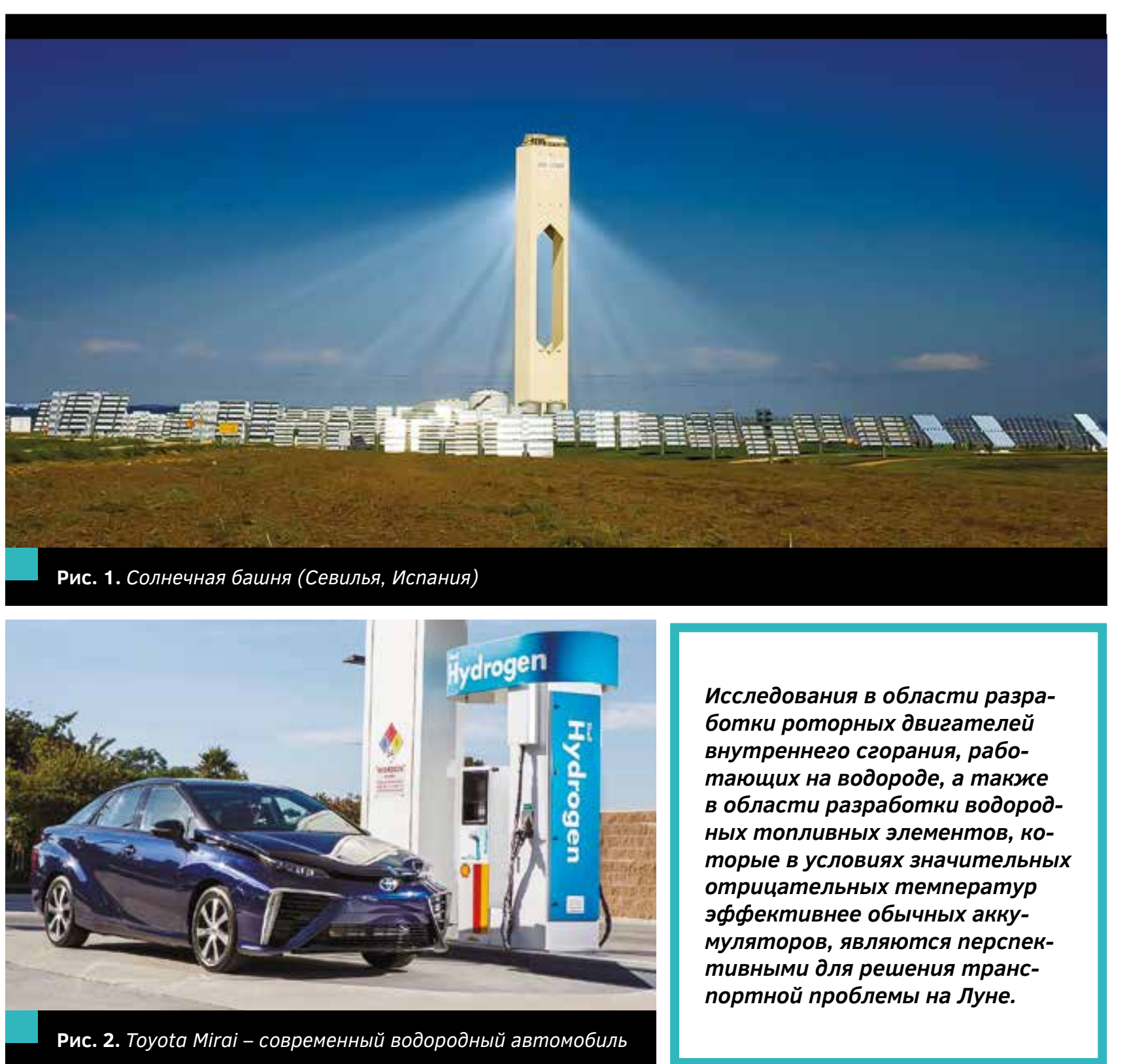

Исследования в области разработки роторных двигателей внутреннего сгорания, работающих на водороде, а также в области разработки водородных топливных элементов, которые в условиях значительных отрицательных температур эффбективнее обычных аккумуляторов, являются перспективными для решения транспортной проблемы на Луне.

ская компания Clean Hydrogen Producers реализовала эту концепцию в виде установки произ зодительностью 10 килограмм водорода в ден туры $2200^{\circ} \mathrm{C}$ при плошади параболических зеркал 92 кв. м [3] (рис. 1).

Не меньшие перспективы для водородной энергетики на Луне возникают и при решении транспортной проблемы, которая является ключевой для исследования поверхности луны, разведки полезных ископаемых, расширения ареала присутствия человека, а также для осуществления грузоперевозок. В этом отношении перспективными являются про- водимые в настоящее время исследования

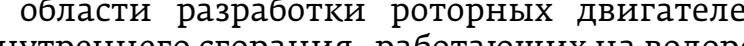
де, а также в области разработки водородных топливных элементов, которые в условиях начительных отрицательных температур эффективнее обычных аккумуляторов. Уже сейчас японская компания Тоуоtа создала конкурентный по сравнению с электромобилями водородный автомобиль, укомплектованный водородным топливным элементом и двум баками для хранения водорода (7о МПа) общей (альс 


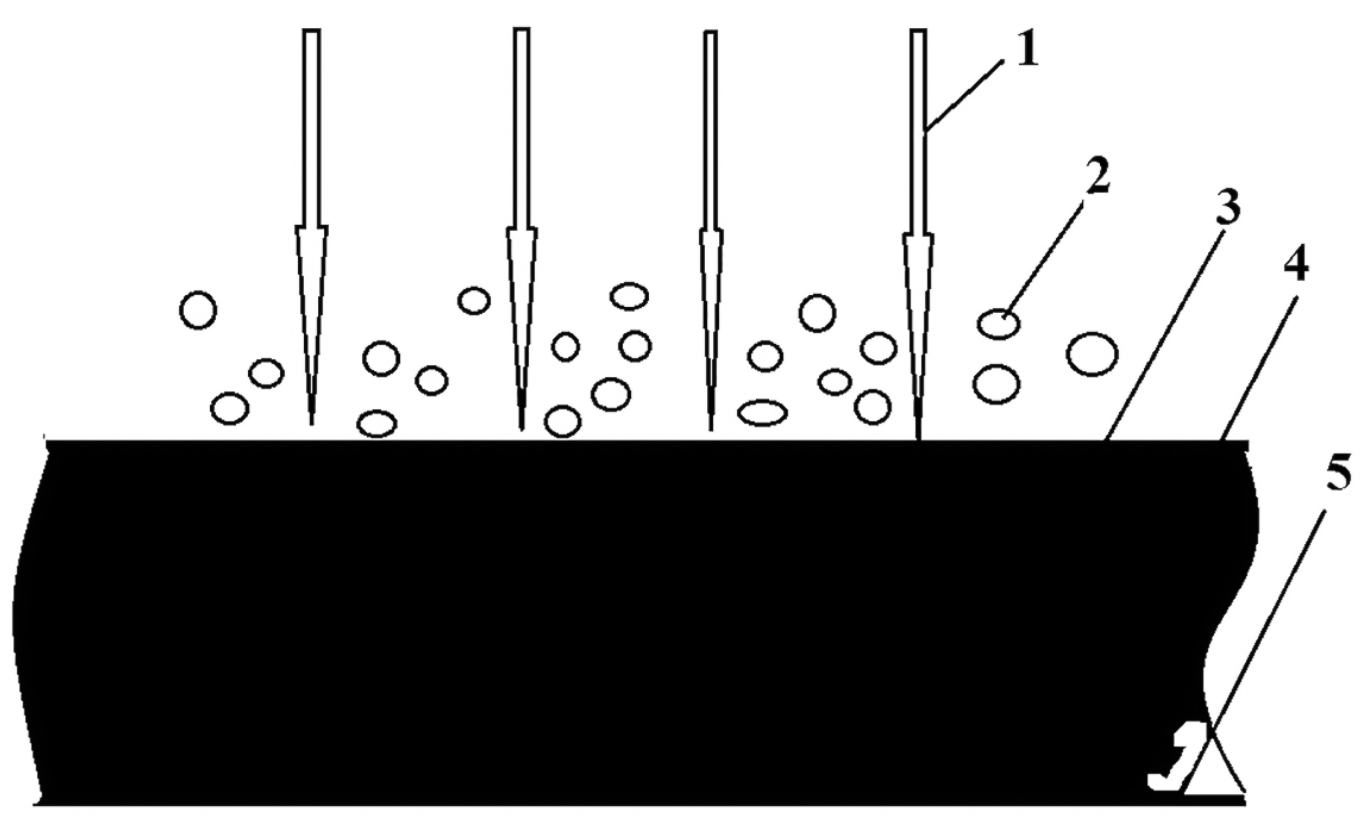

Рис. 3. Модель процесса термоэмиссии паров воды с поверхности слоя реголита (1 - поток солнечн
света, 2 - пары воды, 3 - поверхность реголита, 4 - слой реголита, 5 - базальтовое основание)

Таким образом, перспективы использования достижений водородной энергетики для освоения недр Луны связаны, в первую очередь, с поиском на ее поверхности и в недрах источнико воды, а также возможных источников водород работа технотогий их добычи и изви и раз Сейчас основными районами, где сосредоточены, как предполагают, громадные запасы воды в виде льда, являются затененные полюса Луны (до $50 \%$ по весу от всех запасов воды на Луне), а также области на обратной стороне Лунь (до $20 \%$ по весу от всех запасов воды). Не случайно готовящаяся $\mathrm{k}$ полету на Луну российская космическая станция "Луна-25" планируе совершить посадку именно в приполярной об ласти - это делается для того, чтобы прояснит вопрос о нахождении там воды в замороженбурения на глубину двух метров [4]. Этот факт бул неоднократно подтвержден измерениями которые осуществлены американскими космическими миссиями с использованием таких высоко технологичных приборов, как нейтронный спектрометр, масс-спектрометр для анализа химического состава атмосферы Лун в ультрафиолетовом и видимом диапазоне [5] Одним из важнейших результатов, полученных в ходе этих исследований, был установнечным светом [6]. замороженной в глубинах грунта, переводит ее в жидкое подвижное состояние, И при этом моэмиссии электронов с поверхности нагре ся в объеме твердого тела, источник тепловой

作 ходе этих измерений, была поднята с поверхности Луны и генерируется метеоритами массой около о,15 грамма из так называемого одоносного слоя реголита, накрытого безвод. Пуны, водяные пары в ней появляются не тотеко при бомбардировке ее поверхности метеоритами, но и при простом нагревании ее сол-

В нашей работе представлены результаты фиксации молекул воды над поверхностью одного из крупнейших в видимом полушарии Луны кратера Клавий, находящегося не в полярной области. Поверхность кратера за сче

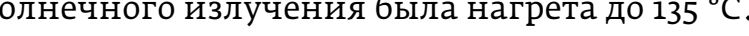
Исследования проводились с помощью инфракрасного телескопа SOFIA, установленного борту самолета "Боинг-747SP", находившегося при измерениях на высоте до 13-14 киломе тров над уровнем моря. Они свидетельствую о том, что в одном грамме лунного грунта со(2) что в пересчете на одну тонну пунного грунта (реголита) составит в среднем 250 мл воды [6]. На первый взгляд, эта цифра незначительна но если учесть, что на Луне этого грунта содер- жится многие миллионы тонн, а сама планета существует в таком состоянии многие миллиосальны (до 5 \% от всех запасов воды на Луне) В связи с этим, может быть, землянам необязательно лететь на южный или северный затемненные полюса Луны, где космонавтов ожидают суровые температурные условия, а следуе сосредоточи

Эти наблюдения и результаты воздействия солнечного света на реголит позволяют вынечным потоком грунт передает тепло воде вода за счет нагрева и осмоса выходит на поверхность грунта, а в дальнейшем испаряется в вакууме над лунной поверхностью. Этот процесс во многом аналогичен процессу тертого катода: в наличии вещество, находящее энергии, который соббщает веществу энергию, состояние с выходом на поверхность твердого тела и испарением в свободное пространство (puc. 3).

Количество испаряющейся воды и динамика вы выхода зависят как от количества поступающей на поверхность твердого тела энергии, так и от того, в каком состоянии в структур ввердого тела находилась вода. или в сорбированном в гранулах реголита, или в свободном замороженном состоянии в пространстве между его зернами. Естесівенн, что выход паров воды в окружающее безвоздушное пространобше погидают поверхность Луны и улетаю в космос. Их выход происходит со скоростями пренебрежительно меньшими, чем скорость в 2,6 км/с (первая космическая скорость для Луны). Поэтому над поверхностью лунного грунта, как и над подогреваемым катодом в электронной лампе, формируется облако водяных частиц, которое непрерывно находится в процессе массобмена с грунтом, а при пере в пе поверхности в тень оседает в нем.

Поскольку длительность дня и ночи на Луне составляет около 14 земных суток, естественно,

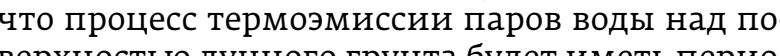
дический харахтер.

Кратко это явление можно было бы назват

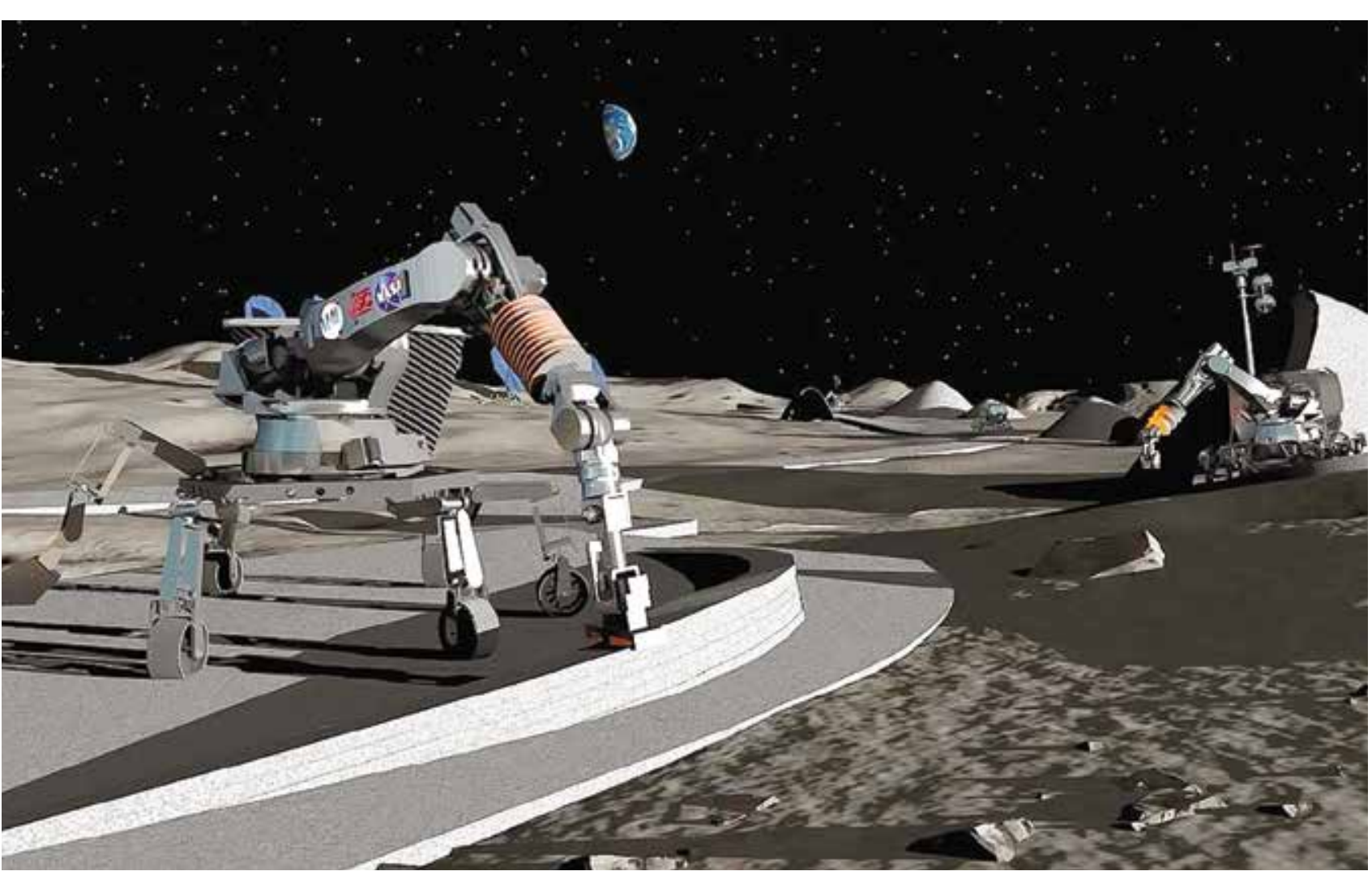


го реголита под действием потока солнечной энергии.

Таким образом, для того чтобы испарить определенное количество воды, находящейся первоначально в одной тонне реголита, необходимо сообщить энергию, достаточную, пературы плавления льда, во-вторых, для плавления этой массы, в-третьих, для нагревания образовавшейся жидкой воды до темпера-
туры кипения, а затем для ее испарения.

Энергетический баланс всего процесса имеет вид:

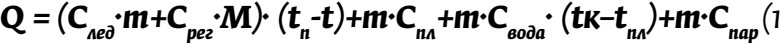

Для оценки величины этой световой энергии (Q) примем, что масса воды в 1 т реголита со$M=1000$ к2, температура реголита с находящимс в нем льдом на глубине 1 м составляет $t=-20^{\circ} \mathrm{C}$ температура плавления льда $t_{n}=0^{\circ} \mathrm{C}$, а температура кипения воды при низком атмосферном давлении составляет $t_{R}=6,7^{\circ} \mathrm{C}$, удельные теплот парообразования и плавления составляют соответственно $C_{\text {nap }}=2,6 \cdot 10^{6}$ Дж/ $/ \mathrm{kz}$ и $C_{\text {n }}=330 \cdot 10^{3}$ Дж/ $/$ к2. При этом удельные теплоты реголита, льда и воды

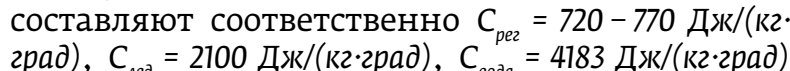

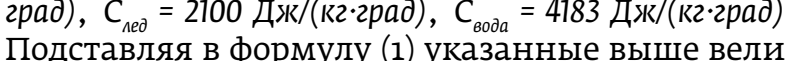
чины, получим, что для реализации процесса термоэмиссии паров воды из лунного грунта необходима энергия равная $Q=16,13 \cdot 10^{6}$ Дж.

При световом потоке, который достигает поерхности Луны, равном $\Phi=1,39 \cdot 10^{3}$ Дж/(сек' M $\left.^{2}\right)$ и коэффициенте поглощения солнечной энерЛуны за 4,1 часа поступят именно те самые $16,13 \cdot 10^{6}$ Дж, которые, согласно проведенным расчетам, были необходимы для реализации процесса термоэмиссии 0,25 кг льда, находящегося в $1 \mathrm{M}^{3}$ лунного грунта. Для наглядност энергия 16,13 МДж - это всего 4,5 кВт.часа, что в современном денежном выражении состав

Эти результаты помогут создать простую технологию получения водяных паров, а затем и кислорода с водородом за счет герметичных реголитов уставльй прохождения солнечных пучей нрынами При этом извлечении воды из паров можно использовать, например, разработанный уче ными Сингапура аэрогель [7], пропуская через него пары воды. Благодаря губчатой структуре аэрогель не нужно сжимать, чтобы получить аккумулятор. Получаемая при этом вода соот ветствует общепринятым для питьевой воды стандартам.

Этот простой способ извлечения паров воды из реголита, наряду с методами получения воды в приполярных областях Луны [8], позво лит обеспечить селенавтов [13] не только водой, но и (после ее термического разложения

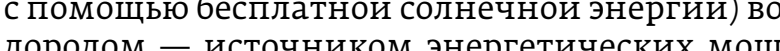
дородом - источником энергетических мощходимо для создания гом ортных условий жизнедеятельности селенавтов, а также реализации технологий добычи, переработки и обогащения полезных ископаемых, составляющих основу освоения недр Луны.

Среди первых претендентов на роль легкодоступных руд является, конечно, лежащий

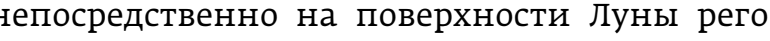

Как показывают многочисленные исследо-

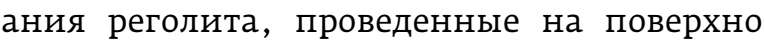
си Луны и в земных лабораториях, в нем содерится еще масса редкоземельных металлов, многие из которых находятся в самородной форме, в том числе цирконий, барий, никель, иттрий и стронций в количестве от 0,1 до $0,02 \%$. В еще меньших количествах рубидий и другие химические этементы. Кроме того, по данным российских исследователей [9], в реголите содержатся уникальные металлические соединения, не характерные для земных естественных условий (в виде оксидов железа, алюминия, титана, магния, натрия, калия и кальция), но являющиеся крайне интересными как конструкционные материалы, а также гелий-3, принесенный космическим ветром на безатмосферную планету [10]. Причем содержание этих полезных ископаемых лунного грунта.

Поэтому неслучайно 6 апреля 2020 года президент США подписал распоряжение, устанавлигосе В этой связи актуальным становится вопрос: хакие именно полезные ископаемые, сосредоточенные в недрах Луны, на таком высоком ровне заинтересовали США? О серьезности намерений Соединенных Штатов свидетельствуе и "Соглашение Артемиды", заключенное с ЕС Канадой, Японией и ОАэ. Однако ни Россия,

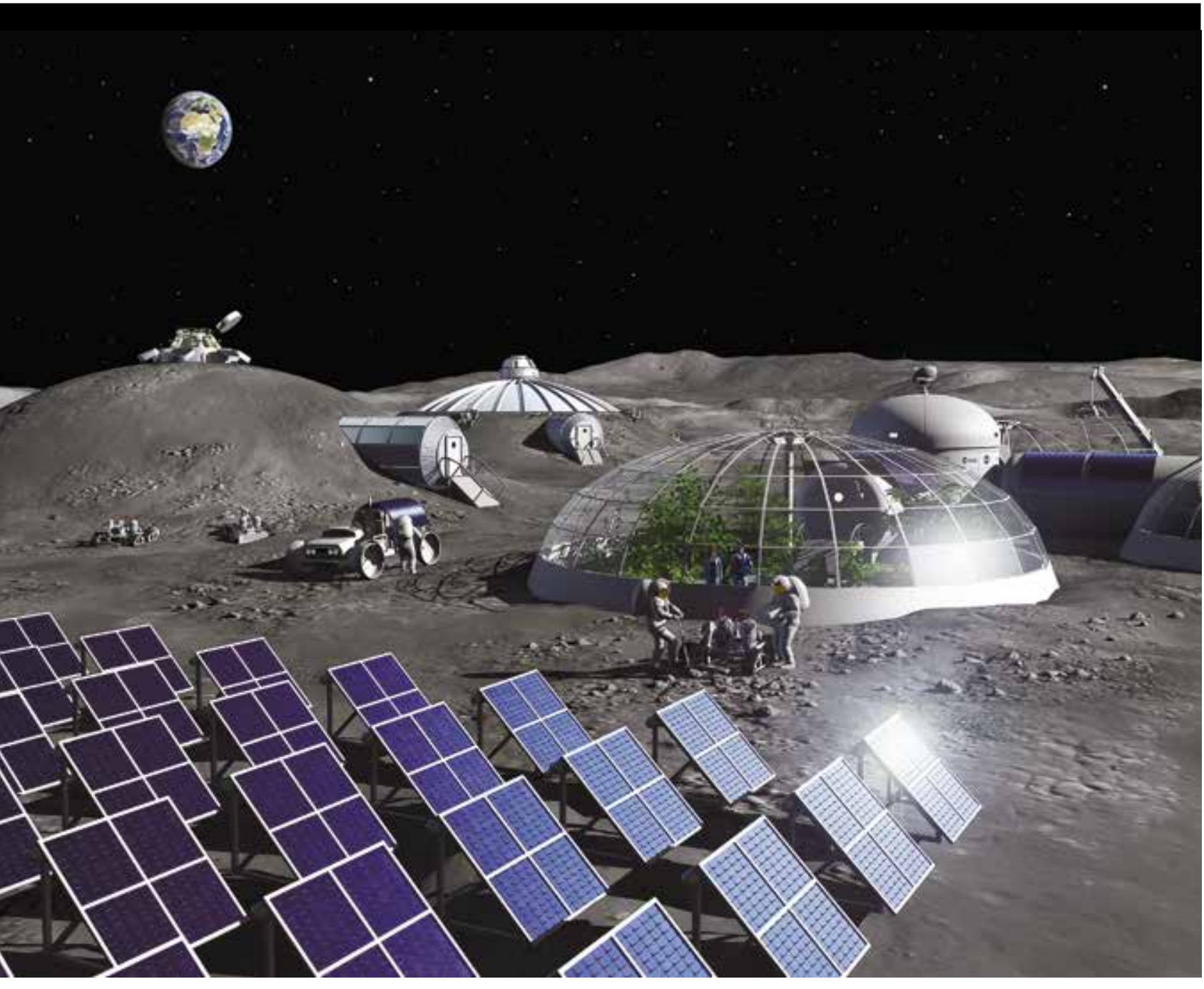

лись. Соглашение предусматривает создание зываемой зоны безопасности для «предотвращения ущерба или вмешательста со сторон стран-конкурентов и компаний». В нем такж сформулирован порядок установления пра собственности на добытые на Луне ресурсы. O серьезности намерений по освоению ресурсов Луны и астероидов свидетельствуе и развернувшаяся в России на площадке МГУ "Диалог о настоящем и будущем" дискуссия "Космические кладовые земли", в рамках котополезных ископаемых [11], В ходе дискуссии, например, ведуший эксперт в области иссте дования Луны профессор В. А. Шевченко сообщил, что, по его оценкам, земных запасов золота, алмазов и цинка на Земле осталось всего на 20 лет, платины, меди, никеля - на 40 лет, а они в первую очередь нужны промышленнопри ближайшем рассмотрении и являются альтернативной "кладовой", в которой содержатся миллионы тонн железа, никеля, кобальта, платины и других металлов. Только за последние несколько лет астрономическими наблюот упавших анте выявлены 222 новых кратера то мненио специалистов, состоит из редкозе мельных металлов [5].

Кроме того, профессор В. А. Шевченко выскаКал гипотезу что редтоземельные металды, такие как золото, платина, никель, литий, появляются в поверхностном слое Луны благодаря, в частности, падению астероидов, кото- 
со скоростью меньше чем $12 \mathrm{kм} / \mathrm{c}$, часть асте-

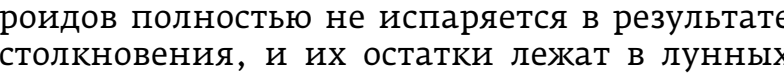
кратерах.

Учитывая, что, например, рыночная стоимость лития составляет несколько тысяч долларов за один килограмм, вероятной и экономически выгодной становится простая доставка с поверхности Луны на землю образ цов редкоземельных металлов с последующей их обработкой. В результате на второй план отодвигается не только проблема формироваредкоземедьные металды, на Луне (то есть проведения цикла хорошо проверенных на земле горнорудных работ), но и планы по разработ ке и апробации дорогостоящей, трудоемкой и сложной технологии изменения орбиты астероида и приближения его к Земле. Последнее при нерасчетных ситуациях может привести к столкновению астероида с Землей.

Однако эта привлекательная гипотеза таковой и останется до тех пор, пока не появятся доказательства наличия редкоземельных ме таллов как в кратерах Луны, так и на самих околоземных астероидах. Уже в 2023 году, когда NASA с зий зонд OSIRIS-REx, запущенный образцы грунта, полученного $с$ поверхности небольшого (в диаметре около $500 \mathrm{M}$ ) астероида Бенну, станет ясно, какие полезные вешеств содержатся в этих пробах грунта.

"Ахиллесовой пятой», этой гипотезы, конечно, является экономическая целесообразность. Доктор И. Моисеев в своей статье в «Независимой газете - науке» напоминает, что доставка 1 кг лунного грунта по программе "Аполлон стоила 397 млн долларов. При этом за шесть ного грунта. Таким образом, если бы все эти образцы состояли из чистых редкоземельных металлов, самый дорогой из которых в настоящее время имеет рыночную стоимость порядка 30 тыс. долларов / кг, стоимость доставленных образцов составила бы всего 11,34 миллион долларов, что является всего 2,8\% от еуммы затраченной на доставку с Луны 1 кг грунта.

Другими словами, чтобы компенсировать затраты на доставку 1 кг грунта в размере 397 млн долларов при цене редкоземельного металла в 30 тыс. долларов / кг, необходимо было б то есть совершить более 210 успешны металла, по маршруту земля - Луна - земля. Если же содержание редких металлов на астероидах или на Луне составит всего несколько первых процентов, проблема их доставки на Землю усложняется, по крайней мере, в 10 раз. Это свидетельствует о том, что ни тогда - в 1970-е годы, ни в ближайшем будущем такая технология не представляется возможной. Тем более для таких важных задач, как сооружение лунных баз и добыча металлов - титана, алюминия и железа, необход

Таким образом, выше приведенные данные и расчеты показывают, что, хотя разработка радй мя и в ближайшем будущем она трудно реализуема без создания на поверхности Луны эффективных источников энергии. И в этом смысле опирающаяся на фундамен-
тальные идеи образования планет Солнечной системы и развития в их недрах геологических процессов водородная энергетика имеет без граничные перспективы развития производиих планетах.
Литература

. Ларин В.Н. гипотеза изначально гидридной земли (новая глобальная концепция). М.: Недра, $1975.101 \mathrm{c}$ 2. Голоскоков А.Н. Критерии сравнения эффентивности традиционных иальтер ливных энергоресурсов // элентронный 2011. № 1. C. $285-299$. 3. Водородные энергетические технолоBэT OИBT PAH. М.: OИBT PAH, 2017. Вып. 1. 190 с

4. Казмерчук П.В., Мартынов М.Б., Москатиньев И.В., Сысоев В.К., Юдин А.Д. Космический а Сарат (Луна-25» - осн им. . . Лавочиина. 2016 № 4 (34) C. $9-19$.

5. Benna M., Hurley D.M., Stubbs T.J., ained by exospheric water Geoscience. 2019. Vol. 12. Pp. $333-338$ . 10.1038/s41561-019-0345-3

6. Honniball, C.I., Lucey, P.G. Li, S. et al. (2021). Molecular water detected on the Vol. 5. Pp. 121 - 127. https://doi. org/10.1038/s41550-020-01222-x 7. Ольга Вашарина. Ученые Сингапура разработали аэрогель для извлечения воды из воздуха [Электронный ресурс] //
Новостной портал FBM.ru. 2021. 22 янваpя. URL: https://ffbm.ru/novosti/science/ phenye-zz-singapura-sozdali-ajerogelvodu.html?utm_source =yxnews\&utm medium=desktop
(Дата обращения: 04.02.2021) 8. Багров А.В., Леонов В.А. Проблемы перехода от исследований Луны к ее освоению // Воздушно-космическая сфе9. Лунный грунт из Моря Изобилия. Мо-

Teid Weiblen P.W., Murawa M.J., and Reid K.J. (1990) Preparation of Engineering, Construction and Operation in Space II, pp. 428 - 435, American Society of Civil Engineers, New York, 11. Шевченко В.В., Постнов К.А. Космические кладовые Земли. Диалог о настоящ и будущем [Электронный ресурс] // Сай
URL: https:// expert.msu.ru/space (Дата

12. Бобин А.В., Бобина В.А. Гироскопические горные машины для освоения солезных ископаемых Луны и строительвоздушно-космическая сфера. 2019. № 2 . C. $26-31$.

13. Бобин В.А., Бобина А.В. Проект создания простейших поселений на эта разведки недр Луны // Воздушно-космис сфера. 2020. № 2. С. $54-61$.

References

Larin V.N. Gipoteza iznachal'no gidridnoj Zemli (novaja global'naja koncepcija). Moscow, Nedra, 1975. 101 p. 2. Goloskokov A.N. Kriterii sravnenija Jefektivnostit tradicionnyh i al'ternativnyh . Vodorodnye jenergeticheskie tehnolog AN. Vol. 1. Moscow, OIVT RAN, 2017. $190 \mathrm{p}$.

\section{Kazmerchuk P.V., Martynov M.B.} Moskatin'ev I.V., Sysoev V.K., Judin A.D. Kosmicheskij apparat "Luna-25" - osnova novyh issledovanii luny. Vestnik NPO im. A. LavochKna, 2016, no. 4 (34)

\section{Benna M., Hurley D.M., Stubbs T.J.,} hydration constrained by exospheric water liberated by meteoroid impacts. Nature Geoscience, 2019, vol. 12, pp. 333 - 338 DOI: 10.1038/s41561-019-0345-3 6. Honniball, C.I., Lucey, P.G., Li, S. et al. (2021). Molecular water detected on the sulit Moon by SOFIA. Nature Astrono org/10.1038/s41550-020-01222-

7 Ol'ga Vasharina Uchenye Singapura razrabotali ajerogel' dlja izvlechenija vody vozduha. FBM.ru. 202 January 22. Available at: https://fbm.ru/ novosti/science/uchenye-iz-singapurasozdali-ajerogel-prevrashhajushhiource $=y \times$ xnews \& 4 tm medium $=$ desktop (Retrieval date: 04.02.2021.

Bagrov A.V., Leonov V.A. Problemy perehoda ot issledovanij Luny k ee osvoen . no. 3, pp. 22 - 33 .
9. Lunnyj grunt iz Morja Izobilija. Moskva,

10. Weiblen P.W., Murawa M.J., and Reid K.J. (1990) Preparation of simulants fon lunar surface materials. Engineering, pp. 428 - 435. American Society of Civil Engineers, New York, NY.

\section{Shevchenko V.V., Postnov K.A.} Kosmicheskie kladovye Zemli. Dialog o
nastojashhem i budushhem. Lomonoso Moscow State University. 2020. May 07. Available at. https:// expert.msu.ru/space

(2. Bobin A.V., Bobina V.A. Giroskopichesk iskopaemyh Luny i stroitel'stva na nej postojannyh poselenij. Vozdushnokosmicheskaja sfera, 2019, no. 2,

pp. $26-31$.

13. Bobin V.A., Bobina A.V. Proekt sozdanija prostejshih poselenij na jetape razvedki .

(๑) Бобин В.А., Бобина А.В., 2021

\section{История статьи:}

Поступила в редакцию: 18.01.2021

Модератор: Плетнер К.В.

Для цитирования:
Бобин В.А., Бобина А.В. Фундаментальные идеи и бу освоения недор Луны // воздушно--космическая сферер. 2021. № 1. С. 58 - 67. 